\title{
Field Performance of Cultivars Nicola and Russet Burbank Micro and Minitubers
}

\author{
Abdellah Radouani • Florian I. Lauer \\ Published online: 13 March 2015 \\ (C) The Author(s) 2015. This article is published with open access at Springerlink.com
}

\begin{abstract}
Tuber yield of plants from three sizes of in vitro produced microtubers were compared to yields of plants from three sizes of greenhouse produced minitubers of Nicola and Russet Burbank. Microtubers were: small-size, 0.2-1.5 g; mid-size, 1.5-3.0 g; and large-size, $>3.0 \mathrm{~g}$. Minitubers were: small-size, 15-20 g; mid-size, 20-40 g; and large-size, $>40 \mathrm{~g}$. Both cultivars produced more tubers with micro than with minitubers, $1,033,333$ vs. 568,750 tubers $/ \mathrm{ha}^{-1}$ for Nicola and 605,417 vs. 482,291 tubers/ha ${ }^{-1}$ for Russet Burbank. Within the same type of tuber, Nicola was not influenced by size. With Russet Burbank, however, large-size microtubers produced the highest number of tubers, 606,875 per ha $^{-1}$, and small-size minitubers gave the lowest tuber number, 409,375 tubers $/ \mathrm{ha}^{-1}$. Regarding tuber yield, the type of tuber did not influence either cultivar. Nicola was influenced neither by type nor by size of tubers. Russet Burbank, however, was sensitive to size of tubers, especially, within minitubers. Large-size mini and microtubers were the most productive, 49 and $40 \mathrm{t} \mathrm{ha}^{-1}$, respectively.
\end{abstract}

Resumen Se compararon los rendimientos de tubérculos de plantas de tres tamaños de microtubérculos producidos in vitro con los de plantas de tres tamaños de minitubérculos producidos en invernadero de Nicola y Russet Burbank. Los microtubérculos fueron de tamaño pequeño, 0.2 a $1.5 \mathrm{~g}$; mediano, 1.5 a $3.0 \mathrm{~g}$; y grandes, $>3.0 \mathrm{~g}$. Los minitubérculos fueron pequeños, 15-20 g; medianos, 20-40 g; y grandes,

\footnotetext{
A. Radouani $(\triangle)$

Domaines Royaux El Boura, P.O.Box 62, Taroudant 83 000, Morocco

e-mail: a.radouani@menara.ma

F. I. Lauer

Department of Horticultural Science, University of Minnesota, 1736

Tatum St., St. Paul, MN 55113, USA

e-mail: lauer002@tc.umn.edu
}

$>40$ g. Ambas variedades produjeron más tubérculos con micro que con minitubérculos, 1'033,333 vs 568,750 tuberculos $/ \mathrm{ha}^{-1}$ para Nicola y 605,417 vs. 482,291 tuberculos $/ \mathrm{ha}^{-1}$ para Russet Burbank. Dentro del mismo tipo de tubérculo, Nicola no estuvo influenciada por el tamaño. Con Russet Burbank, sin embargo, los microtubérculos grandes produjeron el número más alto de tubérculos, 606,875 por $\mathrm{ha}^{-1}$, y los minitubérculos pequeños resultaron en el número más bajo, 409,375/ha ${ }^{-1}$. Respecto al rendimiento, el tipo de tubérculos no influenció a ninguna variedad. Nicola no estuvo influenciada ni por el tipo ni por el tamaño de tubérculo. Russet Burbank, no obstante, fue sensible al tamaño de tubérculos, especialmente entre minitubérculos. Los mini y microtubérculos grandes fueron los más productivos, 49 y $40 \mathrm{t} / \mathrm{ha}^{-1}$, respectivamente.

\section{Keywords Potato $\cdot$ Tuber-size $\cdot$ Dormancy}

\section{Introduction}

An excellent review of microtuber performance was made by Coleman et al. (2001). In general, they suggested that use of microtubers would become increasingly important in seed tuber production programs. Smaller microtubers tend to be more erratic in field performance and are affected by many factors (Donnelly et al. 2003). Khuri and Moorby (1996) reported microtubers smaller than $5 \mathrm{~mm}$ (ca. $0.12 \mathrm{~g}$ ) tended to desiccate under field condition, and were more susceptible to disease. Park et al. (2009) noted microtubers less than $0.5 \mathrm{~g}$ lost moisture content more rapidly than larger ones. Wiersema et al. (1987), using microtubers with an average weight of $0.63 \mathrm{~g}$, found total tuber yield increased with increased size. Total tuber number was equal for microtubers of $0.63 \mathrm{~g}$ and $1.25 \mathrm{~g}$, but less for microtubers of $2.5 \mathrm{~g}$. Tovar et al. (1985) 
reported less tuber yield from plants grown from smaller microtubers than from larger ones.

Levy (1985), Leclerc and Donnelly (1990) and Nasiruddin (1995) obtained a higher number of tubers with microtubers compared to conventional seed. Size of mother tubers affected the number of tubers per unit area (Ranalli 1997). Microtubers produced the highest values, but tuber yield was less than normal because of a large number of small tubers in the progeny of microtubers.

Haverkort et al. (1991) used microtubers weighing less than $0.5 \mathrm{~g}$ and obtained less than half the yield of a conventional crop. The lower yield was due to slow early haulm development preempting use of microtubers in the field as a viable option for seed programs. Bus et al. (1990) reported larger microtubers having more rapid haulm development than smaller ones. Struik and Lommen (1990) reported a delay of 6 weeks in ground cover development by using microtubers compared to normal seed potatoes.

Gopal (1996) and Gopal et al. (1998) reported that green tubers induced in a diffuse light photoperiod had more eyes, 6.0 , than white microtubers, 3.5 , induced in continuous darkness. A greater number of eyes per microtuber may result in better performance of crops grown from these microtubers (Gopal et al. 1997).

The choice of cultivars was arbitrary. Russet Burbank is an older but very important cultivar in the US and Canada while Nicola is a newer cultivar released in Europe. The objective of this study was to compare performance of potato crops grown from mini and microtubers having three sizes each. If field performance was comparable, it might be possible to by-pass the expensive production of minitubers in a glasshouse.

\section{Materials and Methods}

\section{Plant Materials}

The choice of cultivars was arbitrary. We thought it useful to have both a North American (Russet Burbank) as well as a European cultivar (Nicola). Russet Burbank is an older, widely grown cultivar while Nicola is a newer, heavy yielding cultivar.

The scheme of microtuber production is described in Radouani and Lauer (2015). Plantlets were cultured for growth in a liquid nutrient medium for 5 weeks. The composition of this nutrient medium was as follows: MS (1962) supplemented with $\mathrm{NaH}_{2} \mathrm{PO}_{4}, 148 \mathrm{mg} \mathrm{L}^{-1}$; thiamine $\mathrm{HCl}$, $0.4 \mathrm{mg} \mathrm{L}^{-1}$; myo-inositol, $0.4 \mathrm{mg} \mathrm{L}^{-1}$; and sucrose, $30 \mathrm{~g} \mathrm{~L}^{-1}$. This nutrient medium was removed after 5 weeks and replaced with a similar medium, in which sucrose concentration was increased from 30 to $80 \mathrm{~g} \mathrm{~L}^{-1}$, and $\mathrm{NaH}_{2} \mathrm{PO}_{4}$ eliminated This phase was 3 months long.
For minituber production, the same protocol was used for the first 5 weeks in liquid growth medium. They were then transferred to a glasshouse for minituber production; which also had a $\mathrm{CO}_{2}$ system injector. The substrate was $100 \%$ peat moss. Fertigation was done via a drip irrigation system. The density of plantlets per square meter was 62.5 . After 4 months, minitubers were hand-harvested.

\section{Storage Management}

Before harvest of microtubers, the growth room temperature was lowered from 24 to $10^{\circ} \mathrm{C}$ by $1{ }^{\circ} \mathrm{C}$ per day. After harvest, microtubers were blotted dry onto sterile tissue paper to remove medium and reduce probable subsequent contamination before storing (Nasiruddin 1995), and maintained 20 days at $95 \%$ relative humidity and $10{ }^{\circ} \mathrm{C}$ for healing and maturation. Microtubers were graded into three size classes: small-size, 0.2-1.5 g/tuber; mid-size, 1.5-3.0 g/tuber; and large-size, $>3.0 \mathrm{~g} /$ tuber. Minitubers, harvested on first generation ex vitro plants established from in vitro plantlets, were also graded into three sizes: small-size, 15-20 g/tuber; mid-size, 20-40 g/tuber; and large-size, $>40 \mathrm{~g} /$ tuber. Cold storage room temperature was decreased from 10 to $4{ }^{\circ} \mathrm{C}$ over a period of 12 days with an average reduction at a rate of $0.5^{\circ} \mathrm{C} /$ day, and then maintained at $4{ }^{\circ} \mathrm{C}$ for 2 months. The $\mathrm{CO}_{2}$ level was maintained below $1 \%$. There was total darkness during storage. Subsequently, the temperature of the cold storage was increased $0.5^{\circ} \mathrm{C} /$ day until $15{ }^{\circ} \mathrm{C}$ was reached. Pre-sprouting of micro and minitubers was performed over 15 days at a temperature of $15{ }^{\circ} \mathrm{C}$; diffuse light of $20-\mu \mathrm{mol} \mathrm{m}{ }^{-2} \mathrm{~s}^{-1}$ PAR (Photosynthetically Active Radiation), and RH of $95 \%$.

\section{Agronomic Performance}

The experiment was hand-planted February 27 in a light sandy loamy soil: $60 \%$ sand, $30 \%$ loam, less than $10 \%$ clay and less than $1 \%$ organic matter. The field was near Taroudant in southern Morocco. Electro conductivity was 0.8 millimhos/ $\mathrm{cm}^{2}$. Plant spacing was $80 \mathrm{~cm}$ between and $20 \mathrm{~cm}$ within rows. Planting depth for micro and minitubers were 3 and $8 \mathrm{~cm}$, respectively.

A total of 280 units of N, $300 \mathrm{P}$, and $400 \mathrm{~K}$ were applied using a fertigation system. Foliar nutrition was also applied at full leaf coverage: $32.5 \% \mathrm{MgO}, 2 \mathrm{~kg} / \mathrm{ha} ; 6 \% \mathrm{Mn}, 1 \mathrm{l} / \mathrm{ha} ; 9 \%$ $\mathrm{Zn}, 1 \mathrm{1} / \mathrm{ha} ; 16 \% \mathrm{Mg}+11 \% \mathrm{Zn}, 1.5 \mathrm{~kg} / \mathrm{ha}$; and $20 \% \mathrm{~N}+11 \%$ $\mathrm{Mn}+22.8 \% \mathrm{Zn}, 1.5 \mathrm{l} / \mathrm{ha}$.

A drip irrigation system was used with one emitter line per row with $0.40 \mathrm{~m}$ between emitters. Flow rate of the drip irrigation system was $3.12 \mathrm{~mm} / \mathrm{h}$. Irrigation was managed daily on the basis of evapo-transpiration. The cultural coefficient depended on physiological stage. It was 0.3 at the early growth stage (after planting to 3 weeks); 0.6 at relatively good leaf cover (weeks 3-6); 1.0 at tuber formation and bulking 
(weeks 6-14); 0.8 at tuber maturation; and 0.7 before vine killing (weeks 14-16). Water was of good quality (electro conductivity: 0.7 millimhos $/ \mathrm{cm}^{2}$ ). Weeds were hand-pulled and three tillages were carried out by hand. Five pesticide treatments for aphid, three for tuber moth, and two for mites were applied during the culture cycle. Tubers were harvested 120 days after planting, June 29, and lifted by hand.

\section{Data Analysis}

The experimental design was a randomized complete block with five blocks. In both experiments, the experimental units were 4-m long rows with 20 micro or minitubers each. Total tuber number (TTN) and total tuber weight (TTW) data were analyzed using SAS. Randomization was done using STATITCF. Main effects were tested by ANOVA and means separated using the Student-Newman-Keuls test. Tuber number data were normalized with sqrt transformation. Results are presented in non-transformed format and computed to give the yield per hectare (tubers $/ \mathrm{ha}^{-1}$ and tuber weight as metric tons $/ \mathrm{ha}^{-1}$ ).

\section{Results}

Ground cover, 1 month after planting, was almost the same for both types of seed-tubers and for all size classes. This may reflect good preparation of tubers before planting.

For Nicola, plants from all sizes of microtubers were significantly higher in TTN than plants from all sizes of minitubers (Table 1). There were no differences in TTN produced by plants among sizes within either type of mini or microtubers. Plants from small, mid and large-size micro or minitubers gave the same (statistical) TTN.

In contrast to TTN, there were no statistical differences in Nicola plants from all sizes of the two types of seed-tubers for TTW. All of them were sorted in the same statistical homogeneous group. Nicola was neither influenced by size nor type of seed-tubers for TTW.

Russet Burbank reacted differently. Within the same type of seed-micro or seed-minitubers, there was no significant difference among sizes. Plants from large-size microtubers produced more TTN than plants from small-size minitubers. Plants from small and mid-size microtubers were not significantly different from those from mid and large-size minitubers in TTN.

There was no difference between plants from the two types of seed-tubers for TTN. However, within the same type, Russet Burbank was sensitive to minituber size. Within microtubers, there were no significant differences among various sizes. Plants from large-size minitubers and microtubers significantly increased TTW, $49.072 \mathrm{tha}^{-1}$ and $40.328 \mathrm{tha}^{-1}$, respectively. Plants from mid-size and small-size microtubers, and mid-size minitubers produced, statistically, similar TTWs, $32.806,26.356$, and $31.356 \mathrm{t} \mathrm{ha}^{-1}$, respectively. Small-size minitubers had significantly lower TTW, $15.631 \mathrm{t} \mathrm{ha}^{-1}$, than all other categories.

The average TTN produced by Nicola plants derived from microtubers, small, mid and large-size, was 1,033,333 tubers/ $\mathrm{ha}^{-1}$, which significantly exceeded the 568,750 tubers $/ \mathrm{ha}^{-1}$ for plants from minitubers. The increase in TTN by using microtubers was more than $82 \%$. These results were unexpected. In contrast to TTN, there were no statistical differences in plants from all sizes of the two types of seed-tubers for TTW. All of them sorted in the same statistical homogeneous group. Nicola was neither influenced by size nor type of seedtubers for TTW.

Russet Burbank reacted similarly to Nicola. TTN from microtubers were significantly higher, 605,417 tubers $/ \mathrm{ha}^{-1}$, compared to those from minitubers, 482,291 tubers $/ \mathrm{ha}^{-1}$, an increase of $26 \%$. Likewise for average TTW, there were no differences between micro and minitubers.

\section{Discussion}

Pre-sprouting was synchronized for both types and for all sizes, and this may explain differences with other reports. Lommen and Struik (1993) reported that the weight of minitubers at planting may affect sprout growth, emergence, crop establishment, and yield. On the other hand, Kawakami et al. (2005) found, with plants from microtubers, the start of linear increase was later in the leaf area index than with plants from minitubers. Leaf area index was higher, subsequently, in plants from microtubers than from conventional tubers. At maximum shoot growth, both had the same leaf area index. Yield of plants from microtubers was 71 and $90 \%$ for two cultivars, compared to conventional tubers.

The present study indicated Nicola was very sensitive to the type of seed-tubers used. Plants from all sizes of microtubers gave a higher TTN compared to all sizes of minitubers. Russet Burbank was less sensitive than Nicola to seed-tuber types. It also produced more tubers with micro than with minitubers, but the differences were not as extreme as for Nicola. These observations agree with Levy (1985), Leclerc and Donnelly (1990) and Nasiruddin (1995). Kawakami et al. (2003) and Kawakami et al. (2004), however, did not observe significant differences in TTN from plants derived from micro and minitubers. Their microtubers were supplied by the Kiran Brewery Co. Ltd., and may have been more physiologically mature.

Increased TTN could be advantageous for the seed-potato industry. A higher number of tubers are usually beneficial to seed producers. Nevertheless, it appears that each cultivar needs further investigation, since there was an interaction of 
Table 1 Effect of three microtuber and minituber sizes on subsequent field performance

\begin{tabular}{|c|c|c|c|c|c|}
\hline \multirow[b]{2}{*}{ Type of tuber } & \multirow[b]{2}{*}{ Size of tuber } & \multicolumn{2}{|c|}{ Total tuber number/ha ${ }^{-1}$} & \multicolumn{2}{|c|}{ Total tuber weight $\left(\mathrm{t} \mathrm{ha}^{-1}\right)$} \\
\hline & & Nicola & Russet burbank & Nicola & Russet burbank \\
\hline \multirow[t]{3}{*}{ Micro $^{1}$} & Small & $1,125,000 \mathrm{a}$ & $603,125 \mathrm{ab}$ & $50.922 \mathrm{a}$ & $26.356 b$ \\
\hline & Mid & $990,625 \mathrm{a}$ & $606,250 \mathrm{ab}$ & $55.272 \mathrm{a}$ & $32.806 b$ \\
\hline & Large & $984,375 \mathrm{a}$ & $606,875 \mathrm{ab}$ & $55.225 \mathrm{a}$ & $40.328 \mathrm{ab}$ \\
\hline \multirow[t]{3}{*}{$\mathrm{Mini}^{2}$} & Small & $603125 b$ & $409,375 b$ & $50.162 \mathrm{a}$ & $15.631 \mathrm{c}$ \\
\hline & Mid & $562,500 \mathrm{~b}$ & $496,875 \mathrm{ab}$ & $56.609 \mathrm{a}$ & $31.353 b$ \\
\hline & Large & $540,625 b$ & $540,623 \mathrm{ab}$ & $57.978 \mathrm{a}$ & $49.072 \mathrm{a}$ \\
\hline Micro & Average & $1,033,333 \mathrm{a}$ & $605,417 \mathrm{a}$ & $53.806 a$ & $33.163 \mathrm{a}$ \\
\hline Mini & Average & $568,750 \mathrm{~b}$ & $482,291 b$ & $54.916 \mathrm{a}$ & $32.019 \mathrm{a}$ \\
\hline
\end{tabular}

${ }^{1}$ Small-size microtubers, $0.2-1.5 \mathrm{~g} /$ tuber,

Mid-size microtubers, $1.5-3.0 \mathrm{~g} /$ tuber, and

Large-size microtubers, $>3.0 \mathrm{~g} /$ tuber

${ }^{2}$ Small-size minitubers, 15-20 g/tuber,

Mid-size minitubers, $20-40 \mathrm{~g} /$ tuber, and

Large-size minitubers, 40-60 g/tuber

Within a column, means followed by the same letter are not different at $P=0.05$

cultivar x type of seed-tuber. The better performance for TTN of crops grown from microtubers compared to minitubers is not understood. This may be due to microtubers having more eyes than minitubers and consequently more stems producing more tubers. Gopal et al. (1997) support this hypothesis.

Another possibility may be that microtubers are relatively immature compared to minitubers. Microtubers showed little or no apical dominance in this study. This is very surprising in view of the more intensive dormancy inherent in Russet Burbank as well as a number of reports indicating significant dormancy issues in microtubers (Coleman et al. 2001). Perhaps, with the protocol used in this study, the natural gibberellins may play a more dominant role in the development of microtubers as well as in plants for a longer period of time when initiated from these microtubers. Such a situation might increase the number of sinks while reducing the strength of individual sinks, resulting in a higher TTN as observed in this study.

The potential of microtubers in seed potato production programs may be under estimated. Reduced stands, yields and dormancy issues have been reported in studies involving microtubers of $<0.5 \mathrm{~g}$. Field performance, in terms of yield, of larger microtubers in comparison to conventional seed tubers of 40-60 $\mathrm{g}$ has been encouraging. Two sizes of microtubers, $0.5 \mathrm{~g}$ and $1.0-3.0 \mathrm{~g}$, of a late maturing cultivar were compared with conventional seed tubers of $50 \mathrm{~g}$. (Kawakami, et al. 2003). Yield of the smaller and larger microtubers was 71 and $84 \%$, respectively, of conventional seed tubers. Subsequently, Kawakami, et al. (2004) compared two sizes of microtubers, $0.3-1.0 \mathrm{~g}$ and $1.0-3.0 \mathrm{~g}$, of an early maturing cultivar with conventional seed tubers. Yield of the smaller and larger microtubers were 81 and $90 \%$, respectively of conventional seed tubers. However, in a comparison of 1.0 $3.0 \mathrm{~g}$ microtubers of four cultivars ranging in maturity, yield was only $66 \%$ of the conventional seed tubers. In a subsequent study, Kawakami et al. (2006) investigated water stress as a possible source of erratic performance, and concluded that water stress was not a major factor in tuber yield of plants from microtubers.

In the present study, TTW of Nicola plants from microtubers, regardless of size, were statistically identical to the large 40-60 g minitubers. Russet Burbank, however, showed a pronounced increase in TTW with increased microtuber size relative to the large minituber with the small, mid, and large-size yielding 53, 67, and $82 \%$, respectively.

The use of more appropriate tuberization media (Radouani and Lauer 2015) could substantially increase both microtuber number and weight. By increasing $\mathrm{N}$ to $2 \times, \mathrm{P}$ to $3 \times$, and $\mathrm{K}$ to $2 \times$ that of the standard MS (Murashige and Skoog 1962) media concentration (control), TTN for Nicola and Russet Burbank was 51 and $76 \%$ higher, respectively, than the control, and TTW was 63 and $39 \%$ higher, respectively, than the control.

It can be concluded from this study that microtubers can be appropriate for integration into seed potato programs. Their efficiency, compared to conventional seed potato production system using glasshouses, is probably higher. This would positively influence cost and quality of the produced seed and increase potato yield in general. The reader should consider that these field experiments were conducted under 
increasing day length (February 27-June 29). Results would probably vary under different environmental conditions.

Open Access This article is distributed under the terms of the Creative Commons Attribution License which permits any use, distribution, and reproduction in any medium, provided the original author(s) and the source are credited.

\section{References}

Bus, C.B., A.J. Haverkort, P.C. Struik, and D.E. van der Zaag. 1990. Influence of the rate of early growth on the field performance of microtubers in Netherlands, 522-523. Edinburgh: Abstract of the 11th Triennial Conference of the European Association of Potato Research.

Coleman, W.K., D.J. Donnelly, and S.E. Coleman. 2001. Potato microtubers as research tools: a review. American Journal of Potato Research 78: 47-55.

Donnelly, D.J., W.K. Coleman, and S.E. Coleman. 2003. Potato microtuber production and performance: a review. American Journal of Potato Research 80: 103-115.

Gopal, J. 1996. Selection, genetic divergence and cross prediction in potato. Ph.D. Thesis, Punjab Agricultural University, Ludhiana, Punjab., India, $205+$ xviii pp.

Gopal, J., J.L. Minocha, and J.S. Sidhu. 1997. Comparative performance of potato crops raised from microtubers induced in the dark versus microtubers induced in light. Potato Research 40: 407-412.

Gopal, J., J.L. Minocha, and H.S. Dhaliwal. 1998. Microtuberization in potato (Solanum tuberosum L.). Plant Cell Reports 17: 794-798.

Haverkort, A.J., M. Van de Waart, and J. Marinus. 1991. Field performance of potato microtubers as propagation material. Potato Research 34: 353-364.

Kawakami, J., K. Iwama, T. Kasegawa, and U. Jitsuyama. 2003. Growth and yield of potato plants grown from microtubers in fields. American Journal of Potato Research 80: 371-378.

Kawakami, J., K. Iwama, Y. Jitsuyama, and X. Zheng. 2004. Effect of cultivar maturity period on the growth and yield of potato plants grown from microtubers and conventional seed tubers. American Journal of Potato Research 81: 327-333.
Kawakami, J., K. Iwama, and Y. Jitsuyama. 2005. Effects of planting date on the growth and yield of two potato cultivars grown from microtubers and conventional seed tubers. Plant Production Science 8: 74-78.

Kawakami, J., K. Iwama, and Y. Jitsuyama. 2006. Soil water stress and the growth and yield of potato plants grown from microtubers and conventional seed tubers. Field Crops Research 95: 89-96.

Khuri, S., and J. Moorby. 1996. Nodal segments or microtubers as explants for in vitro microtuber production of potato. Plant Cell Tissue and Organ Culture 45: 215-222.

Leclerc, Y., and D.J. Donnelly. 1990. Seasonal differences in the field performance of micropropagated potato under a short growing season in Quebec. American Potato Journal 67: 507-516.

Levy, D. 1985. Propagation of potato by direct transfer of in vitro proliferated shoot cuttings into the field. Scientia Horticulturae 26: 105-109.

Lommen, W.J.M., and P.C. Struik. 1993. Performance of potato minitubers in a controlled environment after different storage periods. Potato Research 36: 283-292.

Murashige, T., and F. Skoog. 1962. A revised medium for rapid growth and bio assays with tobacco tissue cultures. Physiologia Plantarum 15: 473-497.

Nasiruddin, K.M. 1995. Potato microtubers: Their formation and dormancy. Ph.D. Thesis, London University.

Park, S.W., J.H. Jeon, H.S. Kim, S.J. Hong, C. Aswath, and H. Joung. 2009. The effect of size and quality of potato microtubers on quality of seed potatoes in the cultivar 'Superior'. Scientia Horticulturae 120: $127-129$.

Radouani, A, and F. Lauer. 2015. Effect of NPK media concentrations on in vitro potato tuberization of cultivars Nicola and Russet Burbank. Submitted for publication. doi 10.1007/s12230-014-9420-9

Ranalli, P. 1997. Innovative propagation methods in seed tuber multiplication programs. Potato Research 40: 439-453.

Struik, P.C., and W.J.M. Lommen. 1990. Production, storage and use of micro and minitubers, 122-123. Edinburgh: Abstracts of the 11th Triennial Conference of the European Association for Potato Research.

Tovar, P., R. Estrada, L. Schilde-Rentschler, and J.H. Dodds. 1985. Induction of in vitro potato tubers. CIP Circular, International Potato Centre, Lima, Peru. 13: 1-4.

Wiersema, S.G., R. Cabello, P. Tovar, and J.H. Dodds. 1987. Rapid seed multiplication by planting into beds microtubers and in vitro plantlets. Potato Research 30: 117-120. 